\title{
The Impact of Positive Word-of-mouth on Store Brand Purchase Intention with Mediated Effect of Store Image and Perceived Risk towards SBs
}

Azim Zarei ${ }^{1}$ and Ahmad kazemi ${ }^{* *}$

${ }^{1}$ Assistant Professor, Faculty of Management, University of Semnan, Iran

${ }^{2}$ Master of Business Management, University of Semnan, Iran

\begin{abstract}
Several factors (positive word-of-mouth (PWOM), perceived risk toward store brands (SBs) and store image) have been underlined to explain store brand purchase intention in the context of an emerging market (IRAN). Data were collected from a consumer survey with 204 respondents. Structural equation modeling was used to test the hypothesized relationships. The result show that PWOM influence significantly store image. But there is no effect of PWOM, store image and perceived risk toward SBs on SB purchase intention. These findings are discussed and future research is proposed.
\end{abstract}

Keywords: PWOM; SB perceived risk; SB purchase intention; Store image

\section{Introduction}

Store brands (SBs), termed also as private brands or own brands, are brands owned and sold by a retailer in its own outlets. According to Ailawadi and Keller [1], one of store brand's aim is to identify the goods and services of a retailer and differentiate them from those of competitors. Store brands have been increasingly investigated by marketing scholars and focused retail manager's interest [2]. SBs experienced a phenomenal growth in various product categories during the past years [3]. For retailers, SBs become a reliable means to increase sales quickly at a relatively low cost. Consumers are also willing to purchase private brands products (PLMA, 2009). Several factors such as sociological [3], economical [4] and psychological [5-7] factors make consumers interested in buying of SB products.

In this survey, we gave questionnaires to participants who were eligible for (filtering question: buying from Etka store and were familiar with Etka brand) that never been seen in other studies. Therefore, we want to know whether PWOM, SB perceived risk and store image has effect on SB purchase intention with considering that participants. Richardson et al. $[8,9]$ reported that store brand familiarity enhance store brand proneness while reducing extrinsic cue reliance, perceived quality variation and perceived risk of using SB. Because the costumers selected for this study were patron, at this article, we follow several objectives. First, we want to know if positive word-of-mouth (PWOM) will have positive and direct influence on store image and SB purchase intention with considering the fact that consumers use of others' experiences as an informational source when making purchase decision [10-12]. Second, we investigate if store image will have effects on SB purchase intention and SB perceived risk that consumers use of store image cues for purchasing decision [13]. Third, we asses effect of SB perceived risk on SB purchase intention. Extensive research has proved the effect of perceived risk on SB purchase intention [14-16]. The questions that we want to examine of indicated as follows:

1. Will PWOM have positive and direct effect on SB purchase intention?

2. Will PWOM have Positive and direct effect on store image?

3. Will store image have negative and direct effect on SB perceived risk?
4. Will store image have positive and direct effect on SB purchase intention?

5. Will SB perceived risk have negative and direct effect on $\mathrm{SB}$ purchase intention?

\section{Rational for this research}

Supermarket chains have been strengthening their position through mergers and acquisitions. With fewer and bigger players competing in markets, retailers need to assess their strategies carefully, in order to gain market share. Developing a strong store brand can play an important role in this effort. However, a store brand can be highly successful in some product categories while being ineffective in others [17].

There are many incentives for retailers to build store brand programs such as building store loyalty, increasing store traffic, enhancing negotiation strength toward manufacturers, etc.

For retailers, there are several risks in connection with the introduction of new products under a store brand. Store brands are typically umbrella brands, or brand that include various distinct product categories. A negative experience with one product category can prevent consumers from buying store brands in other categories, and even erode customer confidence in the store as a whole [18]. Retailer should therefore first assess the likelihood of acceptance of a new category under the store label. This assessment can be made by investigating consumer evaluations of store brands [19].

Based on what was mentioned above about the store brands and importance of these brands, PWOM can play a significant role in the purchase of store brands. Existing literature on marketing, suggests that WOM has an impressive function at purchase decision [20]. Research, continuously has shown importance of WOM in forming of

*Corresponding author: Ahmad kazemi, Master of Business Management Researcher of Etka Organization Research \& Development Center, University of Semnan, Iran, Tel: +98 9127239320; E-mail: akazemi1354@gmail.com

Received August 04, 2014; Accepted September 03, 2014; Published September 10,2014

Citation: Zarei A, kazemi A (2014) The Impact of Positive Word-of-mouth on Store Brand Purchase Intention with Mediated Effect of Store Image and Perceived Risk towards SBs. J Account Mark 3: 115. doi: 10.4172/2168-9601.1000115

Copyright: (c) 2014 Zarei A, et al. This is an open-access article distributed under the terms of the Creative Commons Attribution License, which permits unrestricted use, distribution, and reproduction in any medium, provided the original author and source are credited. 
attitudes, purchase decision and reduction of risk related to purchase decision. PWOM nowadays is considered as powerful tool that quickly makes unknown and unfamiliar products popular [21]. Writz and chew [22] stated that relationship between customer and organization is most important incentive in creating PWOM. Some models are presented that show people are influenced by others [23].

\section{Conceptualization and hypotheses development}

The role and importance of store brands has been noticeably increased over the past decades. Store brands dramatically are evolving into impressive alternatives capable of competing successfully with national brands on quality as well as on price [24] and contributing substantially to profitability, store differentiation and store loyalty [25]. Sales volume and market share of store brands, as well as their appeal to consumers, have steadily increased [26,27]. Many retailers, instead of being distribution of national brands, would like to market their own brand. Store brands can help retailers to increase customers' traffic and build loyalty to the store by offering high quality store brand.

\section{$P W O M \rightarrow S B$ purchase intention and/or store image}

WOM is informal, interpersonal communication about products and services $[28,29]$. WOM provides important information about a company that helps people to approach to the company or away of it $[30,31]$. Previous studies have extensively examined the effect of PWOM [32,33]. When buying new product, consumers often rely on recommendations received through WOM because it is rapid and cooperative and provides valuable information [34-36]. Some researchers assume that PWOM will invariably lead to action, such as product purchase, on the part of the listener [37,38]. Zamil [39] studied the effect of WOM on consumers' purchase decision. In this study, purchasing behavior of the final consumer was affected by WOM (negative more than positive). Some studies proved that PWOM plays an important role in store image perception, brand selection and etc. WOM is described as the process that allows consumers to share information and opinions that direct buyers toward and away from specific products, brands and services [40]. The basic idea behind WOM is that information about products, services, stores, companies and so on can spread from one consumer to another. In its broadest sense, WOM communication includes any information about a target object (e.g. company, brand) transferred from one individual to another either in person or via some communication medium [41]. Yavas and Shemwell [42] propose WOM as one of the main sources of image formation. Based on the things mentioned above, we propose:

Hypothesis 1: PWOM will have a positive and direct influence on $\mathrm{SB}$ purchase intention.

Hypothesis 2: PWOM will have a positive and direct influence on store image.

\section{Store image $\rightarrow$ SB perceived risk and/or SB purchase intention}

One of the definitions of store image was provided by Martineau. He stated that store image is the concept that shaping in the customer's mind, partly by the functional features and partly by the psychological attributes. Consumers use store image dimension (layout, products, services, etc.) to decide on store brand purchase. Previous studies demonstrated that store image positively influence SB purchase intention (SBPI) [43]. Based on utilization theory, store image can be determinant of product quality [44]. In addition, we can consider store brands as a brand extension of store. Research of brand expansion supports the idea that store association and evaluation by customers can be generalized to store brand [45]. As store image perception provides a highly relevant cue for store brand, the brand acts as an original brand and considered a base for general quality of store brand.

Various researchers stated multiple characteristics as dimension of store. Lindquist [46] considers 9 elements as dimensions of store such as merchandise, service, customer oriented, physical facilities, convenience, promotion, atmosphere, post-buy satisfaction and institutional factors. Bearden et al. [47] conceptualized 7 elements as store image: price, quality, layout, atmosphere, parking, and employees' behavior. In this study, four factors were selected as store image: Employees service, Convenience, merchandise, Price. Semeijn et al. examined the effect of store image and product attributes. Based on the findings there were direct and positive relationship between store image and consumer attitude towards store branded products. It was also cleared that consumers attitudes towards store branded products is inversely related to perceived financial risk. Liljander et al. worked on modeling consumer responses to an apparel store brand (store image as risk reducer). The study showed that the perceived quality and value of the store-branded products depend on: the levels of perceived risk and store image. Both categories influence consumers' willingness to buy the specific store brand category. Store image was also found to mitigate perceived psychosocial. Therefore:

Hypothesis 3: Store image will have a negative and direct influence on perceived risk towards SBs.

Hypothesis 4: store image will have a positive and direct influence on SB purchase intention.

\section{SB perceived risk $\rightarrow$ SB purchase intention}

The Term of perceived risk is derived from psychological field. Bauer [48] believes that consumer behavior is associated with a risk in the sense that any action of a consumer will have consequences which he cannot predict with certainty, and some of which at least are likely to be unpleasant.

Some researchers have recognized perceived risk in the compound of several dimensions that involves functional, financial, social, psychological, and physical risks. These dimensions have been used by many researchers and even developed. Several dimensions of perceived risk have been measured including overall risk, "functional" or "physical" risk, "financial" risk, "performance" risk, etc.

Batra and Sinha [49] and Richardson et al, showed that perceived risk is a key element for understanding consumer behavior toward store brands. Dursun et al. showed that perceived risk of using SB significantly affects purchase intention. Liljander et al. have empirically demonstrated that consumers' perceived financial risk of buying storebranded apparel product negatively influence SB purchase intentions. It Also was confirmed the effect of perceived risk on purchase intention [50]. In our research, SB perceived risk is divided into functional and financial risk. Therefore, we anticipate:

Hypothesis 5: SB perceived risk will have negative and direct influence on SB purchase intention (Figure 1).

\section{Research Methodology}

\section{Data collection and sample}

This research is based on a survey undertaken in the Iranian market. Iran is an emerging market which is best for retail expansion. Etka chain store (has started to work since 1954 and at the present has more than 429 sales centers in Iran) is one of biggest grocery retailers in Iran which serves several kinds of customers (public citizens and 


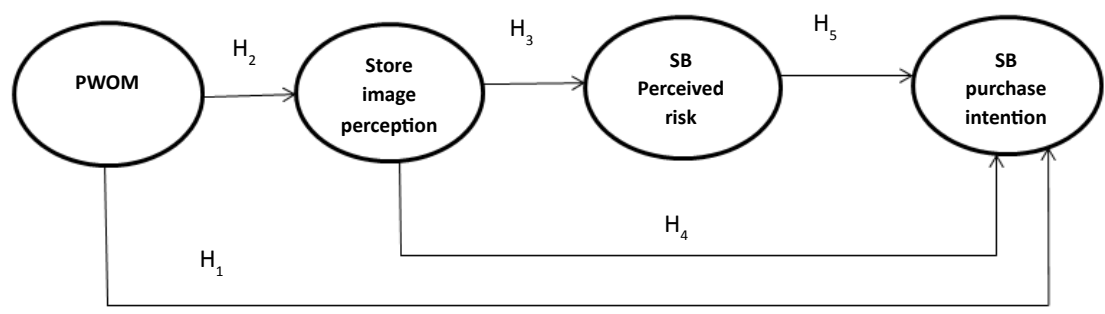

Figure 1: Research conceptual model.

\begin{tabular}{|c|c|c|c|}
\hline Constructs & Dimension and measurement items & Stand. loading & t-values \\
\hline $\begin{array}{l}\text { Store image perception }(\alpha= \\
0.75)\end{array}$ & $\begin{array}{l}\text { Merchandise } \\
\text { Merchandise is available when needed } \\
\text { Store offers high quality merchandise } \\
\text { Store offers broad assortment } \\
\text { Service } \\
\text { Employees behave politely with customers } \\
\text { Employees answer to customers' questions patiently } \\
\text { Employees care about complaints of customers } \\
\text { Convenience } \\
\text { It is convenient to buy from the store for me } \\
\text { I save my time with buying from the store, } \\
\text { Commuting to the Store is easy for me } \\
\text { Perceived price } \\
\text { I obtain value for my money at the store } \\
\text { I can buy products for less at the store } \\
\text { The prices at the store are fair }\end{array}$ & $\begin{array}{l}0.62 \\
0.57 \\
0.69 \\
0.73 \\
\\
0.65 \\
\\
0.84 \\
\\
0.59 \\
\\
0.69 \\
0.48 \\
0.70 \\
0.70 \\
0.87\end{array}$ & $\begin{array}{c}10.90 \\
9.91 \\
12.04 \\
14.17 \\
12.31 \\
16.77 \\
10.22 \\
11.91 \\
7.33 \\
13.71 \\
13.63 \\
17.55\end{array}$ \\
\hline $\begin{array}{l}\text { Perceived risk towards SB } \\
\qquad(\alpha=0.737)\end{array}$ & $\begin{array}{l}\text { Functional risk } \\
\text { You are suspicious of the quality of this SB } \\
\text { You are worried that it is not a wise way of spending money } \\
\text { You are suspicious of ingredients used in its manufacturing } \\
\text { Financial } \\
\text { You think that buying this SB is a waste of money } \\
\text { You think that it is not a wise way of spending money }\end{array}$ & $\begin{array}{l}0.53 \\
0.39 \\
0.31 \\
0.74 \\
0.65\end{array}$ & $\begin{array}{c}9.00 \\
6.40 \\
5.11 \\
12.31 \\
10.98\end{array}$ \\
\hline $\operatorname{PWOM}(\alpha=0.885)$ & $\begin{array}{l}\text { Words of friends and familiars has impact on my shopping of the store } \\
\text { Recommender's credit has impact on my shopping of the store } \\
\text { Good words of others is effective in my shopping of the store }\end{array}$ & $\begin{array}{l}0.47 \\
0.76 \\
0.68\end{array}$ & $\begin{array}{c}7.97 \\
12.88 \\
11.54\end{array}$ \\
\hline $\begin{array}{l}\text { SB purchase intention } \\
\qquad(\alpha=0.717)\end{array}$ & $\begin{array}{l}\text { It is very likely that I will buy SB product } \\
\text { I would purchase SBs next time }\end{array}$ & 0.88 & $\begin{array}{l}5.26 \\
4.88\end{array}$ \\
\hline
\end{tabular}

Table 1: Result of the confirmatory factor analysis $(\mathrm{N}=354)$

families of the Army Forces). Data were collected using a questionnaire (Table 1) and all items were rated on a 5 point-Likert scale (1 "strongly disagree", 2 "disagree", 3 "no agree, no disagree", 4 "disagree" to 5 "strongly agree"). The respondents were intercepted inside of the store when buying. Choiced-based sampling was used to select participants. The criteria for participating were that the respondent must be at least 18 years old and familiar with store brand (Etka) and frequent shopping experience of Etka store. To obtain more accurate results, Distribution of the questionnaires was that after a questionnaire completed by a respondent, another questionnaire was given to next respondent. Distribution of the questionnaire took 23 days (interval between Octobers to November 2013). The number of 380 questionnaires was distributed, that 204 questionnaires were usable and used for analyze (Table 2). 3 out of 7 branches of Etak chain stores in alborz province have been selected. For age, $37.1 \%$ of respondents were between 18 and $20 ; 49.6 \%$ between 35 and 54 and $11.3 \%$ over $54 ; 45.6$ of the respondents were women; for education, $11.9 \%$ of them frequented high school or less; $82.2 \%$ were undergraduate or frequented university and $5.9 \%$ had a master's degree or higher.

\section{Analysis of data and the results}

Measurement scale's factorial structure: In the present research, we used Sps 19 and Lisrel 8.8 software. To determine the patterns the structure each measurement model, we used exploratory factor [51,52]. Based on EFA, the KMO values are greater than 0.7 and Bartlett tests is significant. We kept the items that loaded significantly on only one factor (loading $>0.5$ ) with eigenvalue greater than 1 and communalities $\left(R^{2}\right)$ greater than $67 \%$. All constructs obtained Cronbach alpha greater 


\begin{tabular}{|c|c|c|c|}
\hline Store name (branches) & The Geographical direction & Distributed number \\
\hline Shahid yar mohmadi & North of alborz province & 130 \\
\hline hashtgerd & West of alborz province & 130 \\
\hline marlik & South of alborz province & 130 \\
\hline total & Alborz province & 390 \\
\hline
\end{tabular}

Table 2: The number of questionnaires distributed in each of the branches.

\begin{tabular}{|c|c|c|c|c|}
\hline Variables & & & $\begin{array}{l}\text { Number of } \\
\text { statements }\end{array}$ & Reference \\
\hline & Merchandise & & 3 & $\begin{array}{l}\text { Smeijn et al. } \\
(2004)\end{array}$ \\
\hline \multirow[t]{3}{*}{ Store image } & Service & & 3 & $\begin{array}{l}\text { Wang et al. } \\
(2006)\end{array}$ \\
\hline & Convenience & & 3 & Forsythe (1991) \\
\hline & Perceived price & & 3 & Linduist (1974) \\
\hline \multirow[t]{2}{*}{$\begin{array}{l}\text { Positive word- } \\
\text { of-mouth }\end{array}$} & & & 3 & $\begin{array}{c}\text { Mattlia (2001); } \\
\text { Wong and Sohal } \\
(2002)\end{array}$ \\
\hline & & Financial risk & 2 & Mieres et al. [50] \\
\hline \multicolumn{5}{|l|}{$\begin{array}{l}\text { Perceived risk } \\
\text { towards SB }\end{array}$} \\
\hline & & Functional risk & 3 & \\
\hline $\begin{array}{l}\text { SB purchase } \\
\text { intention }\end{array}$ & & & 2 & $\begin{array}{l}\text { Grewal et al. } \\
\text { [43] Liljander et } \\
\text { al. [14] }\end{array}$ \\
\hline Total & & & 22 & \\
\hline
\end{tabular}

Table 3: The number of statements and used references.

\begin{tabular}{|c|c|c|c|c|c|c|c|c|c|}
\hline $\begin{array}{c}\text { Goodness of fit } \\
\text { index }\end{array}$ & $\frac{\boldsymbol{x}^{2}}{\boldsymbol{d f}}$ & SRMR & AGFI & GFI & IFI & CFI & NNFI & NFI & RMSEA \\
\hline Acceptable values & $1-3$ & $<0.05$ & $>0.9$ & $>0.9$ & $>0.9$ & $>0.9$ & $>0.9$ & $>0.9$ & $<0.1$ \\
\hline Calculated values & 1.53 & 0.043 & 0.95 & 0.97 & 0.97 & 0.97 & 0.96 & 0.91 & 0.039 \\
\hline
\end{tabular}

Table 4: Indices of goodness of fit for the structural model.

\begin{tabular}{|l|c|c|c|}
\hline Hypotheses & $\begin{array}{c}\text { Factor } \\
\text { loading }\end{array}$ & t-test & Result \\
\hline $\mathrm{H}_{1}:$ PWOM $\rightarrow$ SB purchase intention & -0.03 & -0.28 & Rejected \\
\hline $\mathrm{H}_{2}:$ PWOM $\rightarrow$ Store image perception & 0.49 & 6.03 & Confirmed \\
\hline $\mathrm{H}_{3}:$ Store image perception $\rightarrow$ risk towards SBs. & 0.02 & 0.24 & Rejected \\
\hline $\mathrm{H}_{4}:$ Store image perception $\rightarrow$ SB purchase intention & 0.03 & 0.31 & Rejected \\
\hline $\mathrm{H}_{5}:$ Risk towards SBs $\rightarrow$ SB purchase intention & 0.10 & 0.87 & Rejected \\
\hline
\end{tabular}

Table 5: Research results.

than 0.7. We then performed a confirmatory analysis in which we used maximum likelihood (ML) estimation on the covariance matrix with Lisrel 8.8. Table 3 displays the number of statements and used references. To evaluate measurement model fit, some indices applied in the research such as, $\frac{x^{2}}{d f}$, NNFI, NFI, AGFI, GFI, CFI, RMSEA, SRMR.

Structural model and hypothesis testing: The suggested structural model shows a good fit to the data Table 4 . Based on output by LISREL software shown in Table 5, one hypothesis was confirmed and 4 hypotheses were rejected. Regarding to Table 5, factor loading for all variables except a first hypothesis is lower than 0.3 which shows no relationship in four hypotheses. Moreover, the obtained $\mathrm{t}$-value of $\mathrm{H}_{1}$ is higher than 1.96 so in the reliability level of $95 \%$, observed correlation for $\mathrm{H}_{1}$ is significant but $\mathrm{t}$-values of remaining hypotheses are lower than 1.96 which shows no correlation.

Final model Also has been brought in Figure 2 according to the output of LISREL software and factor loading for each of the examined variables have been shown.

\section{Discussion and Conclusion}

Some results obtained were unexpected and need more attention. The hypotheses are described in details. The effect of PWOM on SB purchase intention (Hypothesis 1) was not confirmed. Based on Previous research customers are influenced by word-of-mouth when making purchase decision. Since the respondents were regular customers of Etka store (i.e. they were familiar with Etka brand), so it can be said that customers rely on their own experiences of SB purchase, rather than be influenced by information received from friends and acquaintances. The effect of SB familiarity on SB purchase intention has been proved [15]. The work by Wilson and Peterson, Sundaram and Webster showed that the impact of advice was greatly reduced when the object of the advice was familiar. Correlation between PWOM and store image perception was confirmed (Hypothesis 2). This means customers who purchase from Etka store, sharing some information about the store (price, service, convenience, merchandise) with others and transfer their good experiences to others. Some studies proved that PWOM plays an important role in store image perception, brand selection and etc. The negative and direct effect of store image perception on perceived risk towards SBs was not confirmed (Hypothesis 3). Previous research has shown that store image affects negatively perceived risk towards SBs. It was also not confirmed the effect of store image perception on SB purchase intention (Hypothesis 4). Based on previous studies, customers evaluate SB purchase intention using of store image dimensions (Merchandise, Services, Price, Layout ...). Moreover, Grewal et al. demonstrated the relationship between store image and SB purchase intention. However the study by Diallo rejected the effect of store image on SB purchase intention. Perceived risk is considered as factor that influences customer behavior [53]. It has been previously shown perceived risk influence on SB purchase intention. But it was not confirmed in this study that need more research about this topic. From the perspective of the author Since previous studies (about SB purchase intention) such as this did not use choice-based sampling in which participants were selected through the filtering question that's why most hypotheses were not confirmed and needs more attention and research.

Nowadays, the importance of store brand is quite clear. The findings of this study have implications for decision-makers in the grocery business. In this study, PWOM was identified as effective factor to improve store image. One way of differentiating one store from another is the unique store image offered to customers, consumers use store image as an evaluative criterion in the decision-making process concerning retail outlet selection. To enhance image store, thus word of mouth marketing needs to be taken seriously.

\section{Future Research}

The aim of this paper determines that if the variables used in this research (PWOM. Perceived risk towards SBs, Store image perception) has effect on SB purchase intention among patron customer (who experienced store brand and familiar with store brand). Some obtained results were unexpected. It is, thus requested researchers implement this research in other chain stores on patron customers for support 
Citation: Zarei A, kazemi A (2014) The Impact of Positive Word-of-mouth on Store Brand Purchase Intention with Mediated Effect of Store Image and Perceived Risk towards SBs. J Account Mark 3: 115. doi: 10.4172/2168-9601.1000115

Page 5 of 6

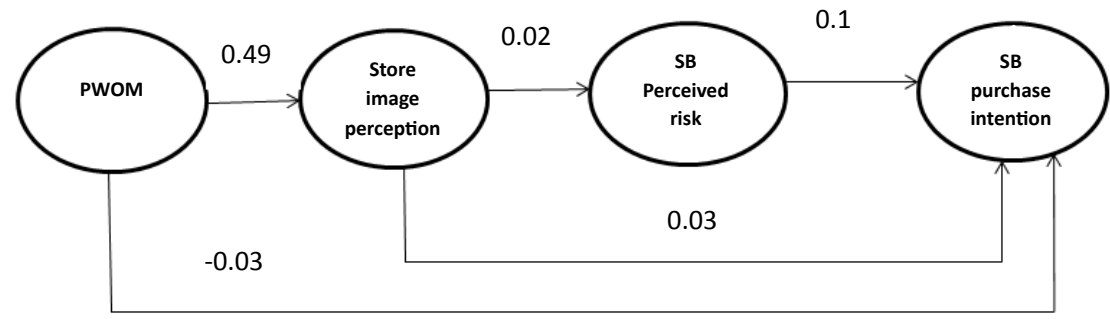

Figure 2: The final model with standard factor loading.

our result. It is also important to use familiarity variable as mediated variable in order to understand whether PWOM, SB perceived risk and store image can effect on SB purchase intention through familiarity.

\section{References}

1. Ailawadi $\mathrm{KL}$, Keller $\mathrm{KL}$ (2004) Understanding retail branding conceptual in sight sand research priorities. J Retailing 80: 331-342.

2. Hyman MR, Kopf DA, Lee D (2010) Review of literature -future research suggestions: private label brands: benefits, success factors and future research. Journal of Brand Management 17: 368-389.

3. Baltas, G, Argouslidis C (2007) Consumer characteristics and demand for store brand. International Journal of Retail and Distribution Management 3: 328-341.

4. Lamey L, Deleersnyder B, Dekimpe MG, Steenkamp JBEM (2007) How business cycles contribute to private-label success: evidence from the United States and Europe. Journal of Marketing 71: 1-15.

5. Garretson JA, Fisher D, Burton S (2002) Antecedents of private label attitude and national brand promotion attitude: similarities and differences. J Retailing 78: $91-99$.

6. Jin B, Suh YG (2005) Integrating effect of consumer perception factors in predicting private brand purchase in a Korean discount store context. Journal of Consumer Marketing 22: 62-71.

7. Kara A, Rojas-Me'ndez JI, Kucukemiroglu O, Harcar T (2009) Consumer preferences of store brands: role of prior experiences and value consciousness. Journal of Targeting 17: 127-137.

8. Dick A, Jain A, Richardson P (1996) How Consumers Evaluate Store Brands. Journal of Product and Brand management 5: 19-28.

9. Richardson P, Jain AK, Dick AS (1996) Household store brand proneness: A framework. J Retailing 72: 159-185.

10. Burnkrant RE, Cousineau $A$ (1975) Informational and normative social influence in buyer behavior. J CONSUM RES 2: 206-215.

11. Pincus S, Waters LK (1977) Informational social influence and product quality judgments. J APPL PSYCHOL 62: 615-619.

12. Venkatesan M (1966) Experimental study of consumer behavior conformity and independence. J Marketing Res 3: 384-387.

13. Richardson PS, Dick AS, Jain AK (1994) Extrinsic and intrinsic cue effects on perceptions of store brand quality. J Marketing 58: 28-36.

14. Liljander VP, Polsaa P, Riel A (2009) Modeling Consumer Responses to and Apparel Store Brand: Store Image as a Risk Reducer. Journal of Retailing and Consumer Services 16: 281-290.

15. Dursun I, Kabadayi ET, Alan KA, Sezen B (2011) Store Brand Purchase Intention: Effects of Risk, Quality, Familiarity and Store Brand Shelf Space. Journal of Retailing and Consumer Services 24: 1190-1200.

16. Diallo MF (2012) Effects of store image and store brand price-image on store brand purchase intention: Application to an emerging market. Journal of Retailing and Consumer Services 19: 360-367.

17. Hoch SJ, Banerii S (1993) when do Private Labels Succeed? Sloan Manage Rev 34: 57-67.

18. Thompson S (1999) The new private enterprise. Brand week 40: 36-40.

19. Sethuraman R, Cole C (1999) Factors influencing the price premiums that consumers pay for national brands over store brands. Journal of Product and Brand Management 8: 340-351.
20. Chevalier JA, Mayzlin D (2003) The Effects of Word of Mouth on Sales: online Book Review. J Marketing Res XLIII: 345-354.

21. Wangenheim FV, Bayon T (2004) The effect of word of mouth on services switching: Measurement and moderating variables. European Journal of Marketing: 1173-1185.

22. Writz J, Chew P (2002) The Effects of Incentives, Deal proneness, Satisfaction and Tie Strength on Word of Mouth Behavior. International Journal of service Industry Management 13: 141-162.

23. Godes D, Mayzlin D (2004) Using online conversations to study word-of-mouth communication. Market Sci 23: 545-560.

24. Quelch JA, Harding D (1996) Brands versus private labels: Fighting to win. Harvard Bus Rev 74: 99-110.

25. Corstjens M, Lal R (2000) Building store loyalty through store brands. J Marketing Res 37: 281-291.

26. Dunne D, Narasimhan C (1999) The new appeal of private labels. Harvard Bus Rev 77: 41-52.

27. Nandan S, Dickinson R (1994) Private brands: major brand perspective Journal of Consumer Marketing, 11: 18-28.

28. Liu $Y$ (2006) Word of mouth for movies: its dynamics and impact on box office revenue. J Marketing 70: 74-89.

29. Richins M, Root-Shaffer T (1988) The role of involvement and opinion leadership in consumer word-of-mouth: an implicit model made explicit. Adv Consum Res 15: 32-36.

30. Lundeen HK, Harmon LC, McKenna-Harmon KM (1995) Service recovery in commercial real estate management. Journal of Property Management 60: 30 32.

31. Zeithaml VA, Parasuraman A, Berry L (1985) Problems and strategies in services marketing. J Marketing 49: 33-46.

32. Sundaram DS, Webster C (1999) The role of brand familiarity on the impact of word-of-mouth communication on brand evaluation. Adv Consum Res 26 : 664-670.

33. Mangold WG, Miller F, Brockway GR (1999) Word-of-mouth communication in the service marketplace. Journal of Services Marketing 13: 73-89.

34. Arndt $\mathrm{J}$ (1967) Role of product-related conversations in the diffusion of a new product. J Marketing Res 4: 291-295.

35. East R, Hammond K, Lomax W (2008) Measuring the impact of positive and negative word-of-mouth on brand purchase probability. Int J Res Mark 25: 219 221.

36. Herr PM, Kardes FR, Kim J (1991) Effects of word-of-mouth and productattribute information on persuasion: an accessibility-diagnosticity perspective. J Consum Res 17: 454-62.

37. Maxham JG (2001) Service recovery's influence on consumer satisfaction, positive word-of-mouth, and purchase intentions. J Bus Res 54: 11-24.

38. Reichheld FF, Sasser Jr WE (1990) Zero defections: quality comes to services Harvard Bus Rev 105-111.

39. Zamil AM (2011) The Impact of Word-of-Mouth (WOM) on the Purchasing Decision of the Jordanian Consumer. Research Journal of International Studies 20: $24-29$.

40. Hawkins DI, Best R, Coney KA (2004) Consumer Behavior: Building Marketing Strategy, McGraw-Hill, Boston. 
Citation: Zarei A, kazemi A (2014) The Impact of Positive Word-of-mouth on Store Brand Purchase Intention with Mediated Effect of Store Image and Perceived Risk towards SBs. J Account Mark 3: 115. doi: 10.4172/2168-9601.1000115

41. Brown TJ, Barry TE, Dacin PA, Gunst RF (2005) Spreading The word: Antecedents of consumers' positive word-of-mouth intentions and behaviors in a retailing context. Journal of Academy of Marketing Science 33: 123-138.

42. Yavas U, Shemwell DJ (1996) Competing for patients and profit. Journal of Health Care Marketing 16: 30-7.

43. Grewal D, Levy M (2009) Emerging issues in retailing research. J Retailing 85: $522-526$

44. Semeijn J, Van Riel ACR, Ambrosini AB (2004) Consumer evaluations of store brands: An effect of store image and product attributes. Journal of Retailing and Consumer Services 11: 247-258.

45. Collins-Dodd C, Lindley T (2003) Store brand and retail differentiation: the influence of store image and store brand attitude on store own brand perceptions. Journal of Retailing and Consumer Services 10: 345-352.

46. Lindquist JD (1974) Meaning of image - a survey of empirical and hypothetical evidence. J Retailing 50: 29-38.
47. Bearden WO, Eeel JE, Durand RM (1978) Media usage, Psychographics and demographic dimensions of retail shoppers. J Retailing 54: 65-74.

48. Bauer RA (1960) Consumer behavior at risk taking. Harvard University Press, Boston.

49. Batra R, Sinha I (2000) Consumer-level factors moderating the success of private label brands. J Retailing 76: 175-191.

50. Mieres CG, Martin AMD, Gutierrez JAT (2006) Antecedents of the difference in perceived risk between store brands and national Brand Promotions. Journal of Marketing 65: 71-89.

51. Anderson JC, Gerbing DW (1998) Structutal equation modeling in practice: a review and recommended two-step approach. Psychol Bull 103: 411-423.

52. Churchill GA (1979) A paradigm for developing better measures of marketing constructs. J Marketing Res 16: 64-73.

53. Pavlou PA (2003) Consumer acceptance of electronic commerce: integrating trust and risk with the technology acceptance model. Int J Electron Comm 7: 101-134. 